\title{
Enhanced microbial nitrogen transformations in association with macrobiota from the rocky intertidal
}

\author{
Catherine A. Pfister ${ }^{1}$ and Mark A. Altabet ${ }^{2}$ \\ ${ }^{1}$ Department of Ecology and Evolution, University of Chicago, Chicago, IL, USA \\ ${ }^{2}$ School of Marine Sciences, University of Massachusetts Dartmouth, Dartmouth, MA, USA \\ Correspondence: Catherine A. Pfister (cpfister@uchicago.edu)
}

Received: 19 April 2018 - Discussion started: 17 May 2018

Revised: 2 December 2018 - Accepted: 8 January 2019 - Published: 18 January 2019

\begin{abstract}
Microbial nitrogen processing in direct association with marine animals and seaweeds is poorly understood. Microbes can both attach to the surfaces of macrobiota and make use of their excreted nitrogen and dissolved organic carbon (DOC). We tested the role of an intertidal mussel (Mytilus californianus) and red alga (Prionitis sternbergii), as well as inert substrates for microbial activity using enclosed chambers with seawater labeled with ${ }^{15} \mathrm{~N}$-enriched ammonium and nitrate. Chambers with only seawater from the same environment served as a control. We found that $3.21 \mathrm{nmol}$ of ammonium per gram of dry mass of mussel, on average, was oxidized per hour, while $1.60 \mathrm{nmol}$ of nitrate was reduced per hour. Prionitis was associated with the oxidation of $1.50 \mathrm{nmol}$ of ammonium per gram of wet mass per hour, while $1.56 \mathrm{nmol}$ of nitrate was reduced per hour. Inert substrates produced relatively little change compared to seawater alone. Extrapolating to a square meter of shoreline, microbial activity associated with mussels could oxidize $2.5 \mathrm{mmol}$ of ammonium and reduce per $1.2 \mathrm{mmol}$ of nitrate per day. A square meter of seaweed could oxidize $0.13 \mathrm{mmol}$ ammonium per day and reduce the same amount of nitrate. Seawater collected proximal to the shore versus $2-5 \mathrm{~km}$ offshore showed no difference in ammonium oxidation or nitrate reduction. Microbial nitrogen metabolism associated with mussels was not influenced by the time of day. When we experimentally added DOC (glucose) as a carbon source to chambers with the red alga and inert substrates, no change in nitrification rates was observed. Added DOC did increase dissolved inorganic nitrogen (DIN) and phosphorus uptake, indicating that DOC addition stimulated heterotrophic microbial activity, and suggests potential competition for DIN between heterotrophic and chemolithotrophic
\end{abstract}

microbes and their seaweed hosts. Our results demonstrate that microbes in direct association with coastal animals and seaweeds greatly enhance nitrogen processing and likely provide a template for a diversity of ecological interactions.

\section{Introduction}

Anthropogenic doubling of the supply of biologically available nitrogen (Galloway et al., 2008; Fowler et al., 2013) has increased the importance of understanding the multiple components of the nitrogen cycle. In marine ecosystems, microbial activity has been shown to be a key driver in the nitrogen cycle, and while phototrophs can dominate uptake in the water column (Flombaum et al., 2013), chemolithotrophs and chemoheterotrophs have also been shown to be quantitatively significant to nitrogen cycling (Capone et al., 2008; Francis et al., 2007; Zehr and Ward, 2002). In coastal marine areas, the large biomass of macrofauna and macrophytes presents the opportunity for microbial taxa to form associations where microbes have habitat as well as a predictable nitrogen supply (Moulton et al., 2016). Many of these macrobiota are restricted in movement, making them reliable substrates for microbial populations.

There are many quantitative estimates of microbial nitrogen fluxes, including ammonium oxidation (nitrification), in seawater from disparate open-ocean locales (Beman et al., 2011; Ward and Bouskill, 2011). Comparatively, there is little knowledge of the microbially mediated nitrogen fluxes associated with nearshore species, including whether the presence of animal and plant hosts enhance the diversity and/or intensity of microbial functions. With the harvest and loss 
of many marine species (Maranger et al., 2008; Worm et al., 2006), the importance of determining the biogeochemical role of microbes associated with macrobiota becomes more urgent. Here, we quantify microbial nitrogen processing in coastal and offshore water and in association with two key coastal species. Because dissolved organic matter is one of the microbial resources supplied by macrobiota in aquatic systems (Hansell and Carlson, 2015), we also manipulated dissolved organic carbon (DOC) concentration to examine the effect of carbon availability on microbial nitrogen processing.

Across diverse aquatic ecosystems, the metabolic activities of animals and plants can generate the environmental niches necessary for a variety of microbial metabolisms (Allgeier et al., 2014; Croll, 2005; Layman et al., 2011; Schindler et al., 2001; Subalusky et al., 2015; Vanni, 2002). Animals and plants create strong gradients in oxygen and inorganic and organic nutrients such that processes that vary over hundreds of meters or kilometers in the open ocean can change over scales of millimeters in proximity to an animal (de Goeij et al., 2013) or over a scale of meters relative to species aggregations (Clasen and Shurin, 2015). With respect to temporal variation, the photosynthetic and respiratory processes of coastal biota can drive wide fluctuations in oxygen, possibly leading to both oxidizing and reducing microbial metabolisms in the same location over a diel cycle (e.g., de Goeij et al., 2013; Pfister et al., 2016).

While strong gradients in biogeochemical cycling and associated microbial activity have been demonstrated in soft sediment communities (Eyre et al., 2011; Grossmann and Reichardt, 1991; Murray et al., 2015), there is increasing documentation that microbial nitrogen processing, including nitrification and nitrate reduction, is enhanced in proximity to surface-dwelling animals in marine systems (Heisterkamp et al., 2013; Pfister et al., 2014a, b, 2016a; Stief, 2013; Welsh and Castadelli, 2004). These enhanced nitrogen metabolisms also contribute to nitrous oxide production (Heisterkamp et al., 2010, 2013), as well as to the retention of nitrogen (Pfister et al., 2016).

A further influence of macrobiota on microbial metabolisms, particularly seaweeds, is the production of dissolved organic matter (Reed et al., 2015). Macroalgae produce DOC, likely influencing microbial metabolism. DOC release by macroalgae may stimulate heterotrophic nitrate reduction, where microbes respire DOC with nitrate $\left(\mathrm{NO}_{3}^{-}\right)$or nitrite $\left(\mathrm{NO}_{2}^{-}\right)$as alternative electron acceptors. DOC can also stimulate the oxidation of $\mathrm{NH}_{4}^{+}$through heterotrophic nitrification (e.g., Joo et al., 2005). In addition to promoting microbial transformations between $\mathrm{NH}_{4}^{+}$and $\mathrm{NO}_{2} / \mathrm{NO}_{3}$, enhancing the DOC supply can result in competition between different microbial metabolisms for dissolved inorganic nitrogen (DIN). Work in streams suggests heterotrophic bacteria may compete with chemolithotrophs for DIN (Butturini and Sabater, 2000), a result that may depend upon the ratio of $\mathrm{C}: \mathrm{N}$ of available substrates, where increasing DOC increases $\mathrm{C}: \mathrm{N}$ and promotes nitrogen competition (Strauss and Lamberti, 2000). In sum, increasing the supply of DOC to marine microbes could have opposing effects on nitrification rates. While an increase in ammonium oxidation would indicate stimulation of heterotrophic nitrifiers, a decrease in $\mathrm{NH}_{4}^{+}$oxidation rate would be consistent with increased competition for $\mathrm{NH}_{4}^{+}$ with heterotrophic microbes. Though the precise role of DOC in nitrogen metabolisms is likely varied and still not fully described, DOC contributes greatly to heterotrophy in microbes and fuels the quantitatively significant "microbial loop" (Azam, 1998).

Because the effects that macrobiota have on both nitrogen excretion and DOC release remain poorly understood, we tested how the presence of the California mussel (Mytilus californianus), a red alga (Prionitis sternbergii), and the proximity to shore affected microbial nitrogen transformations during both daylight and nighttime periods. We know that both species have a diverse microbial community (Pfister et al., 2014b) and that mussels are a source of nitrogen. Further, Prionitis is a common tide pool alga in association with animals. We thus hypothesized that macrobiota (both mussels and algae) would enhance microbial nitrogen cycling and nearshore seawater would have greater microbial activity compared with offshore because it was in close proximity to the macrobiota. We used gas-tight chambers and added ${ }^{15} \mathrm{~N}$-enriched ammonium or nitrate to estimate the flux of ammonium and nitrate attributable to microbial activity. Further, gas-tight chambers allowed us to test whether microbial denitrification resulted in loss of nitrogen via $\mathrm{N}_{2}$ gas. By quantifying nitrification, nitrate reduction, and denitrification, we could distinguish nitrogen retention versus loss. We then manipulated DOC (in the form of glucose) to test its specific effects on nitrogen transformations. In sum, we asked the following questions. (1) How does the presence of mussel, red algal tissue, or inert substrates affect microbial nitrogen cycling? (2) Does the microbial activity in seawater differ between nearshore and 2-5 km offshore? (3) Are there diel cycles in these microbial nitrogen transformations? And (4) does the addition of dissolved organic carbon alter microbial nitrogen metabolism?

\section{Materials and methods}

\subsection{Chambers for assaying microbial metabolisms}

In order to quantify how microbial nitrogen transformations contribute to loss and retention of dissolved nitrogen we enclosed seawater and some components of the rocky shore environment within two gas-tight Plexiglas chambers. Each $2.26 \mathrm{~L}$ chamber measured approximately $15 \mathrm{~cm}$ in diameter, $30 \mathrm{~cm}$ in height, and contained two ports at the top: one for an o-ring-sealed connection to an oxygen probe and the other with a septate lid for gas-tight sampling of seawater. 
From 29 June to 22 August 2012, 54 assays (27 pairs) were done in the chambers either in situ in tide pools $2 \mathrm{~km}$ east of Neah Bay, WA, USA; at Second Beach, WA $(n=19)$ $\left(48.23^{\circ} \mathrm{N}, 124.40^{\circ} \mathrm{W}\right)$; at the shore at Tatoosh Island, WA ( $n=26,48.39^{\circ} \mathrm{N}, 124.74^{\circ} \mathrm{W}$ ); or onboard the R/V Clifford A. Barnes using seawater $2-5 \mathrm{~km}$ from each of these shorebased sites $(n=4)$. By using paired statistical contrasts to compare the treatments described below, we minimized the possibility that environmental variation drove differences between treatments. The Second Beach site is described in Pather et al. (2014) and has tide pools at a height of 1.2 to $1.5 \mathrm{~m}$ above Mean Lower Low Water (MLLW), with a diversity of species (described in Pfister, 2007; Pfister et al., 2016). The chambers were anchored into a number of these tide pools for $3-5 \mathrm{~h}$ at a time during periods of low tides when the tide pools were emergent. Thus, the chambers contained tide pool water and were incubated to approximately half of their height $(15 \mathrm{~cm})$ under natural light and temperature conditions. Temperature could differ depending on the amount of sun and the air temperature during a given day and ranged from 10.9 to $21.4^{\circ} \mathrm{C}$, though it was most often in the range of 13.0 to $14.0^{\circ} \mathrm{C}$. Experimental trials included tide pool seawater only $(n=5)$, seawater with the California mussel Mytilus californianus ( $n=9$, estimated mean dry mass $=4.4 \mathrm{~g}$ ), or seawater with bioballs and ceramic rings ( $n=5$ or 6 each). Bioballs are topographically complex $26 \mathrm{~mm}$ plastic balls used in commercial aquaria to provide substrate for microbes with an estimated $15-20 \mathrm{~cm}^{2}$ surface area, while Filstar ${ }^{\mathrm{TM}}$ ceramic rings ( $1 \mathrm{~cm}$ diam) are also used in filtration and have an estimated $6 \mathrm{~cm}^{2}$ surface area (Aquatic Eco-systems ${ }^{\mathrm{TM}}$ ). Both inert substrates were anchored in the tide pools for 1 month to enable a natural microbial community to develop prior to the experiments.

Because wave action was more significant at Tatoosh Island, chambers were placed on shore in a $15 \mathrm{~cm}$ water bath within a shaded styrofoam cooler rather than in tide pools. The cooler, with shading, protected the seawater from reaching high temperatures. The chambers were filled with seawater at the shore of Tatoosh Island and contained seawater only $(n=8)$, seawater with the California mussel Mytilus californianus $(n=9$, mean estimated dry mass $=6.2 \mathrm{~g}+2.6 \mathrm{SD})$, seawater with mussel shells only $(n=3$, mean estimated dry mass $=3.9 \mathrm{~g}+1.6 \mathrm{SD})$, seawater with the red alga Prionitis sternbergii $(n=3$, estimated wet mass $=40.0+12.5 \mathrm{SD}$ $\mathrm{g})$, or seawater with bioballs $(n=3)$. Bioballs had been incubated at the lower edge of the mussel bed for 1 month prior to use in the chambers. For all experiments, the wet mass of Prionitis was weighed with a Pesola ${ }^{\mathrm{TM}}$ spring scale, while the mussel dry mass was estimated from individual length measurements of the mussels (Wootton, 2004). For the treatment with mussel shells only, animal tissue was removed immediately prior to the assay, thus testing the role of microbes residing only on the shell. By doing the experiments at each site, mussels and Prionitis were always collected at the site of the experiment, inert substrates were incubated at each site, and seawater was local. We were thus able to make chamber incubations as realistic as possible. Some of the above paired replicates of seawater versus mussels were run during night hours to test for diel differences in microbial activity.

Microbial nitrogen metabolisms were compared in shorebased seawater collections versus seawater collected offshore in 2012. The offshore samples were collected with a CTD Rosette system with $10 \mathrm{~L}$ Niskin bottles on the R/V Clifford A. Barnes 2-5 km offshore from Tatoosh Island $\left(48.432^{\circ} \mathrm{N}, 124.73^{\circ} \mathrm{W}\right)$ or Second Beach $\left(48.37^{\circ} \mathrm{N}\right.$, $124.57^{\circ} \mathrm{W}$ ) at a depth of $1 \mathrm{~m}$ and adding ${ }^{15} \mathrm{~N}$-enriched ammonium. The offshore assays were done with the chambers in a cooler with a water bath onboard the ship deck, again with a depth of $15 \mathrm{~cm}$. Water temperature ranged from 10.7 to $15.5^{\circ} \mathrm{C}$, with most assays in the range of 11.0 to $12.0^{\circ} \mathrm{C}$. We compared ammonium oxidation in four replicates of each shore and offshore chambers during June and July of 2012 by pairing our offshore assays done aboard the R/V Clifford A. Barnes with assays run at the shore at Tatoosh Island or Second Beach within a week of two of the offshore assays.

We initiated each run by filling the chamber with seawater and any macrobiota or bioballs. Oxygen and temperature were immediately recorded by a probe that remained in the chamber through the duration of the experiment. We added sufficient volume of $0.05 \mathrm{M}$ of ${ }^{15} \mathrm{~N}$-labeled ammonium chloride solution $\left({ }^{15} \mathrm{NH}_{4} \mathrm{Cl}\right)$ or sodium nitrate solution $\left(\mathrm{Na}^{15} \mathrm{NO}_{3}\right)$ to achieve an approximate enrichment of $\delta^{15} \mathrm{~N}$ of $10000 \%$ (Cambridge Isotopes). We thus increased ${ }^{15} \mathrm{~N}-\mathrm{NH}_{4}^{+}$or ${ }^{15} \mathrm{~N}-\mathrm{NO}_{3}^{-}$by a factor of 10 with the intention of maximizing our ability to detect the enriched signal in dissolved $\mathrm{N}_{2}$ gas. Both ammonium and nitrate concentrations in seawater in this region are typically high ( $>2$ and $>10 \mu \mathrm{mol} \mathrm{L}{ }^{-1}$, respectively), minimizing any concentrationrelated effects from a tracer addition that ranged from only 8 to $40 \mu \mathrm{L}$. The chamber was agitated by hand to mix the tracer and then agitated three to four more times during the 3 to $5 \mathrm{~h}$ incubation period (approximately once per hour). No samples were taken during the incubation so that we did not compromise the gas-tight nature of the chambers. At the end of the incubation, we inserted a needle attached to a gas-tight syringe through a rubber septa, drew out seawater, and injected this into a $30 \mathrm{~mL}$ serum vial with a rubber stopper that had been evacuated to 160 mTorr with a Welch 8905 vacuum pump. Samples had no head space and were stored at room temperature.

\subsection{Testing the effects of adding DOC}

We hypothesized that heterotrophic microbes in association with phototrophs would have the capacity to increase nitrification with added DOC. We thus compared bioballs and the red alga Prionitis to seawater in an additional experiment in 2014. We tested whether DOC additions enhanced microbial nitrogen processing by increasing the concentration of DOC approximately 6 times above the ambient nearshore concen- 
tration to $1000 \mu \mathrm{M}$ DOC. We added $1.0 \mathrm{~mL}$ of a $1.96 \mathrm{M}$ glucose solution to one chamber at the beginning of the experiment while the other served as a control across all paired experiments. We used glucose as a source for DOC because it is general carbon and energy source for many organisms, facilitating comparison with other published studies. All paired experimental runs with added glucose were performed at Tatoosh Island and resulted in eight paired runs with seawater, and four paired experiments each with either bioballs or Prionitis (mean wet mass $=14.13 \mathrm{~g}+4.61 \mathrm{SD}$ ). We used an enrichment target of $2000 \%$ of $\delta^{15} \mathrm{NH}_{4}$ (as $0.001 \mathrm{M}$ ammonium chloride, ${ }^{15} \mathrm{NH}_{4} \mathrm{Cl}$ ), a decreased enrichment compared to those described above because we were not trying to detect an enriched signal in $\mathrm{N}_{2}$ gas. This tripling of ${ }^{15} \mathrm{~N}^{-} \mathrm{NH}_{4}^{+}$allowed us to test whether ammonium oxidation changed with added DOC; an increase in ammonium oxidation would indicate stimulation of heterotrophic nitrifiers, while a decrease would be consistent with increased competition for nitrogen by heterotrophs.

\subsection{Quantifying enrichment results}

In all experiments, a water sample was collected prior to tracer addition $\left(T_{\mathrm{o}}\right)$ to quantify concentrations of ammonium, nitrate, nitrite, phosphorus, and silica, as well as natural abundance isotope levels of $\delta^{15} \mathrm{NH}_{4}, \delta^{15} \mathrm{NO}_{2}$, and $\delta^{15} \mathrm{NO}_{3}$. For all experiments, we used these initial measures to calculate the subsequent change in enrichment in unlabeled $\mathrm{N}$ pools for rate determination. For labeled forms of N, these data were used to calculate enrichment levels after the addition of tracer. We collected the $T_{\mathrm{O}}$ sample by filtering $\sim 180 \mathrm{~mL}$ of source water through a syringe filter (Whatman GF/F) into HDPE (high-density polyethylene) bottles, which we kept frozen until analysis. For the final sample $\left(T_{\mathrm{f}}\right)$ after $3-5 \mathrm{~h}$ of incubation, we filtered directly from the individual chamber. All nutrient concentrations were analyzed at the University of Washington Marine Chemistry Laboratory (methods from UNESCO, 1994), while isotope determinations were done at the University of Massachusetts Dartmouth using methodology for isotopic composition reported previously (Pather et al., 2014; Pfister et al., 2014b, 2016). Briefly, nitrogen stable isotopes of ammonium were measured according to a modified version of the $\mathrm{NH}_{4}^{+}$oxidation method detailed in Zhang et al. (2007). Ammonium is oxidized to nitrite using a hypobromite solution and then reduced to $\mathrm{N}_{2} \mathrm{O}$ using a sodium-azide-acetic-acid reagent before analysis on an IRMS (isotope ratio mass spectrometer). The stable isotope ratios of nitrate were measured by cadmium reduction to nitrite, followed by reaction with azide to $\mathrm{N}_{2} \mathrm{O}$ (McIlvin and Altabet, 2005). For the DOC analysis, an additional $25 \mathrm{~mL}$ were filtered into a $40 \mathrm{~mL}$ VOA vial (Shimadzu Corp.) and analyzed at the University of Washington Marine Chemistry Laboratory. We tested for the presence of enriched $\mathrm{N}_{2}$ gas in the chambers deployed in 2012 using sample collection and analytical procedures described in Charoenpong et al. (2014). Chamber oxygen and temperature were recorded with a Hach ${ }^{\mathrm{TM}} \mathrm{HQ} 4 \mathrm{D}$ and a LDO probe. All comparisons of the effect of each substrate type on nitrogen processing was assessed with ANOVA or paired $t$ tests using R (https://www.r-project.org/, last access: November 2018). Due to heteroscedastic variance in rate estimates, log transformations were used.

\subsection{Quantifying microbial transformations}

Stable isotope enrichment experiments quantify nitrogen processing in marine environments by tracking the transfer of the tracer between its source and product pools (Glibert et al., 1982; Lipschultz, 2008). The traditional isotope tracer transfer model generally involves estimating a single rate parameter from time 0 to time $t$ (Lipschultz, 2008) and has the general form

Rate $=\left(R_{k}(t)-R_{k}(o)\right) /\left[\left(R_{\mathrm{S}}(o)-R_{k}(o)\right) \cdot \Delta t\right] \cdot[\bar{k}]$,

where $k$ is the sink or product pool at time $t$ (or the average $\bar{k}), s$ is the source pool, and $R$ designates the atom \% $\left({ }^{15} \mathrm{~N} /\left({ }^{15} \mathrm{~N}+{ }^{14} \mathrm{~N}\right) \times 100\right)$ of either the source or sink. The source-product model (Eq. 1) is thus used to estimate individual nitrogen transformation rates. We estimated ammonium oxidation by quantifying ${ }^{15} \mathrm{~N}$ enrichment in nitrite following ${ }^{15} \mathrm{NH}_{4}^{+}$addition. Similarly, nitrate reduction to nitrite was estimated from ${ }^{15} \mathrm{~N}$ enrichment in nitrite following ${ }^{15} \mathrm{NO}_{3}$ addition.

A previous study of enrichment in tide pools showed substantial oxidation and reduction in inorganic nitrogen that was best described with differential equation models fit to multiple time points and underestimated with source-product models (Pfister et al., 2016). Source-product models likely underestimated the oxidation of ammonium here too because remineralization by species within the chamber diluted the ${ }^{15} \mathrm{NH}_{4}^{+}$tracer. We nevertheless used the simpler sourceproduct models because we had only a two-sample proto$\mathrm{col}$, at the beginning and the end of the experiment, to prevent gas escape. Isotope dilution is important and indicates ammonium remineralization by species within the chamber. We quantified ammonium remineralization in chambers with ${ }^{15} \mathrm{NH}_{4}^{+}$tracer using the methods of Pather et al. (2014). Briefly by fitting an exponential model to the decline in $\delta^{15} \mathrm{NH}_{4}$ from the beginning to the end of the experiment $y=a e^{-b x}$. The parameters $a$ and $b$ were fitted where $b$ was the exponential decay constant in the $\delta^{15} \mathrm{~N}_{\mathrm{NH}_{4}}$ enrichment. Remineralization rates were thus calculated as

$\mathrm{NH}_{4}^{+}$remineralization $=|-b| \cdot\left[\overline{\mathrm{NH}_{4}}\right]$

in $n m o l L^{-1} h^{-1}$, where $\left[\overline{\mathrm{NH}_{4}}\right]$ was the mean concentration of ammonium in $\mathrm{nM}$ at the beginning and end of the experiment. 

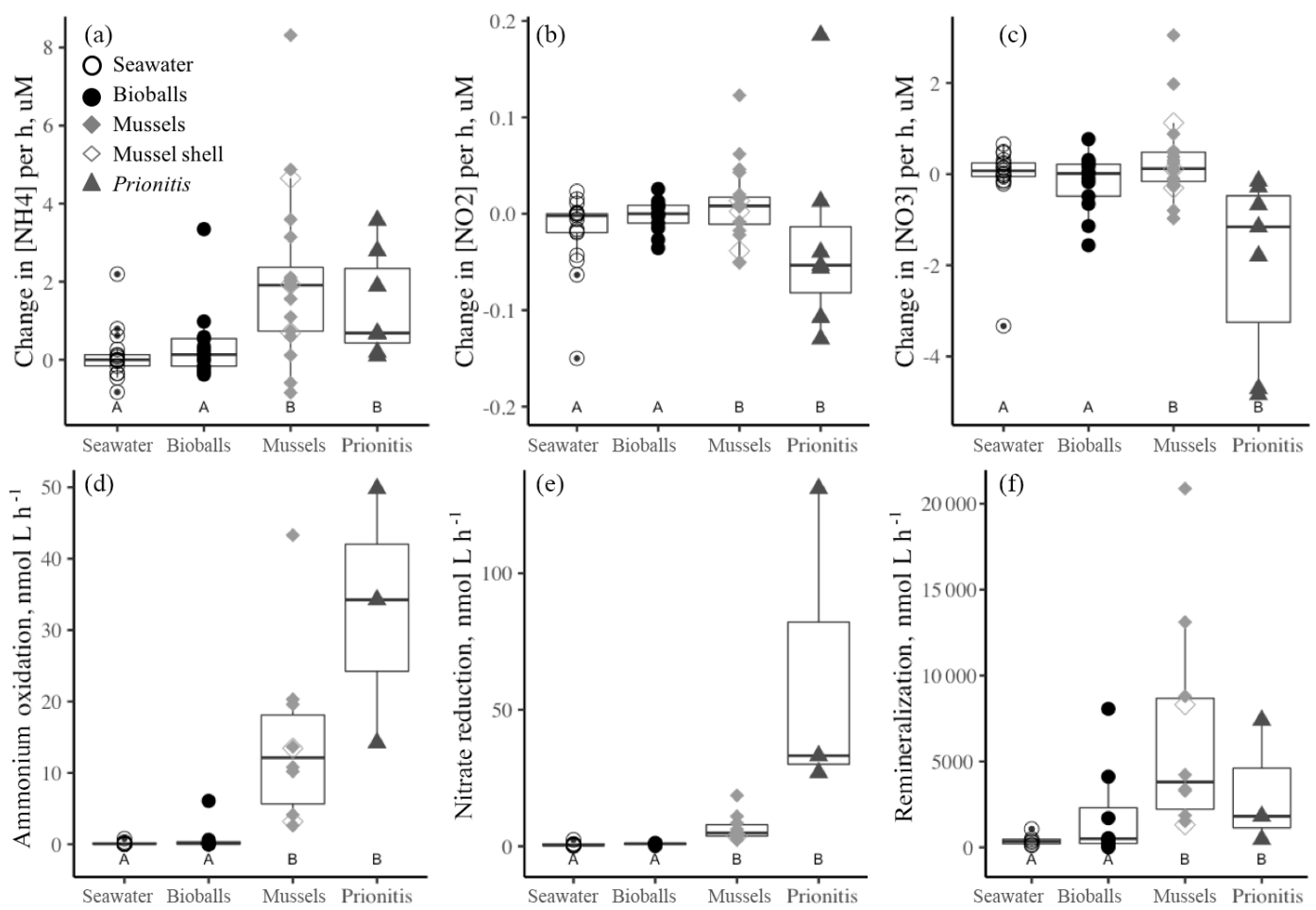

Figure 1. The change in the concentrations of DIN (a ammonium, b nitrite, $\mathbf{c}$ nitrate) in $\mu \mathrm{Mh}^{-1}$ over the course of daytime experiments when only seawater was present versus the addition of bioballs, mussels, or Prionitis displayed as boxplots. Nitrogen transformation rates (in nmol $\mathrm{L}^{-1} \mathrm{~h}^{-1}$ ) for (d) ammonium oxidation, (e) nitrate reduction, and (f) the ammonium remineralization rate. Letters indicate statistical differences with ANOVA and Tukey HSD. The box shows $50 \%$ of the data, the horizontal line is the median, and the vertical lines represent the first and fourth quartiles. Where vertical lines are absent, they are contained within the boxes. Outliers are shown as individual points outside the vertical lines and are 1.5 times the value beyond the top or bottom of the box.

\section{Results}

\subsection{Dynamics of nutrients and isotopes in chambers}

The presence of either the California mussel or the red alga Prionitis amplified net changes to ammonium and nitrate concentration in the experimental chambers compared with chambers that contained bioballs or only coastal seawater during daylight hours (Fig. 1). Chambers during daylight hours with Prionitis and mussels had increased ammonium over the course of the experiment compared with the relatively unchanged coastal seawater and bioball treatments (Fig. $1 \mathrm{a}, F_{5,51}=6.150, p<0.001$ ), while nitrate decreased with Prionitis and increased with mussels (Fig. 1c, $\left.F_{5,51}=3.512, p=0.008\right)$. Changes in nitrite did not differ among treatments (Fig. 1b, $F_{5,51}=0.66, p=0.659$ ).

The dynamics of $\delta^{15} \mathrm{~N}_{\mathrm{NH}_{4}}, \delta^{15} \mathrm{~N}_{\mathrm{NO}_{2}}$, and $\delta^{15} \mathrm{~N}_{\mathrm{NO}_{3}}$ within the chambers revealed transfer of ${ }^{15} \mathrm{~N}$ isotope and thus microbial transformations. When ${ }^{15} \mathrm{~N}^{-\mathrm{NH}_{4}^{+}}$was added, enrichment in $\delta^{15} \mathrm{~N}_{\mathrm{NO}_{2}}$ and $\delta^{15} \mathrm{~N}_{\mathrm{NO}_{3}}$ and any dilution in the $\delta^{15} \mathrm{~N}_{\mathrm{NH}_{4}}$ signal was measured (Fig. A1a, b). Similarly, enrichment in $\delta^{15} \mathrm{~N}_{\mathrm{NH}_{4}}$ and $\delta^{15} \mathrm{~N}_{\mathrm{NO}_{2}}$ followed the addition of ${ }^{15} \mathrm{~N}^{-\mathrm{NO}_{3}^{-}}$(Fig. A1c, d). Deviations in our target of initial enrichment (10000\%o and $2000 \%$ o) occurred due to natural variation in nutrient concentrations at the time of tracer addition, which was factored into rate calculations.

\subsection{Nitrogen transformation rates}

Microbial nitrogen processing rates increased when either the California mussel or the red alga Prionitis was present. Ammonium oxidation rates with the mussel (mean of $\left.14.1 \mathrm{nmol} \mathrm{L}^{-1} \mathrm{~h}^{-1}\right)$ or red alga $\left(32.8 \mathrm{nmol} \mathrm{L}^{-1} \mathrm{~h}^{-1}\right)$ were 2 orders of magnitude greater than ammonium oxidation in seawater only or with bioball surfaces which were less than $1 \mathrm{nmol} \mathrm{L}^{-1} \mathrm{~h}^{-1}$ (Fig. 1d, $F_{5,25}=15.19, p<0.001$, logged values; untransformed values in Table 1). Our estimates of nitrate reduction from the addition of $\mathrm{Na}^{15} \mathrm{NO}_{3}$ were also 2 orders of magnitude greater with Prionitis $\left(63.7 \mathrm{nmol} \mathrm{L}^{-1} \mathrm{~h}^{-1}\right)$ and mussels $\left(6.7 \mathrm{nmol} \mathrm{L}^{-1} \mathrm{~h}^{-1}\right)$ compared with bioballs and seawater (Fig. 1e, $F_{5,19}=17.64, p<0.001$, logged values; untransformed values in Table 1). For all these estimates of microbial nitrogen processing, we found high overlap in the rates estimated with living, intact mussels compared with mussel shells only, indicating that the responsible microbes reside on the shell surface, rather than the mussel tissues (Fig. 1d, e). The presence of mussels was further associated with increased ammonium remineralization and was double 
Table 1. The mean (and standard error) rates of nitrification and nitrate deduction in chambers with seawater, bioballs, mussels, and the red alga Prionitis, expressed as nanomoles (nmol) per liter per hour, nanomoles per gram mass per hour, and as a daily rate in nanomoles for a square meter of rocky shore, respectively.

\begin{tabular}{llll|lll}
\hline & \multicolumn{3}{c}{ Mean nitrification rates (SE) } & \multicolumn{3}{c}{ Mean nitrate reduction rates (SE) } \\
\cline { 2 - 7 } & $\mathrm{nmol} \mathrm{L}^{-1} \mathrm{~h}^{-1}$ & nmol g mass $^{-1} \mathrm{~h}^{-1}$ & $\mathrm{mmol} \mathrm{m}^{2} \mathrm{day}^{-1}$ & $\mathrm{nmol} \mathrm{L}^{-1} \mathrm{~h}^{-1}$ & $\mathrm{nmol} \mathrm{g} \mathrm{mass}^{-1} \mathrm{~h}^{-1}$ & $\mathrm{mmol} \mathrm{m}^{2} \mathrm{day}^{-1}$ \\
\hline Seawater & $0.17(0.09)$ & - & - & $0.71(0.26)$ & - & - \\
Bioballs & $0.82(0.66)$ & - & - & $0.82(0.25)$ & - & - \\
Mussels & $14.1(3.80)$ & $3.21(0.64)^{\mathrm{a}}$ & $2.50(0.50)$ & $6.70(1.56)$ & $1.60(0.41)^{\mathrm{a}}$ & $1.20(0.30)$ \\
Prionitis & $0.82(10.31)$ & $1.50(0.27)^{\mathrm{b}}$ & $0.13(0.08)$ & $63.70(33.70)$ & $1.56(0.72)^{\mathrm{b}}$ & $0.13(0.08)^{\mathrm{b}}$ \\
\hline
\end{tabular}

a designates dry mass, ${ }^{\mathrm{b}}$ designates wet mass.
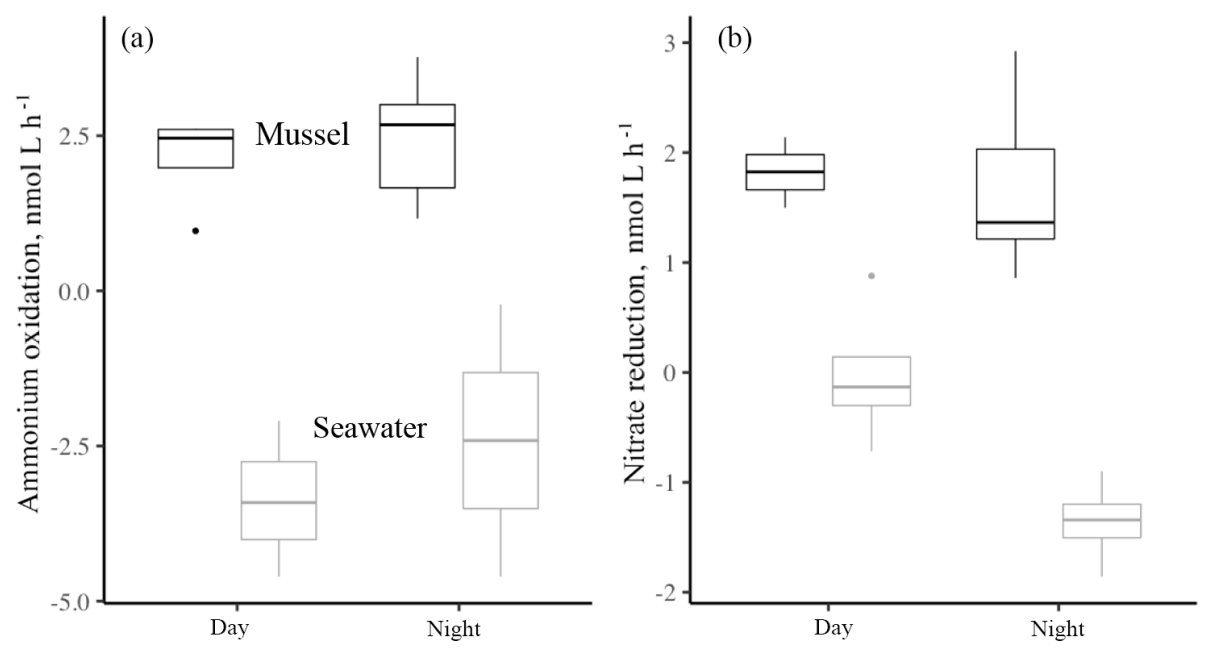

Figure 2. The ammonium oxidation rate (a) and the nitrate reduction rate (b) contrasted between day and night hours for mussels or seawater at the shore. Data are log-transformed (from nmol $\mathrm{L}^{-1} \mathrm{~h}^{-1}$ ) to facilitate comparison. Rates with mussels were always greater (for a $F_{1,11}=52.59, p<0.001$; and $\left.\mathbf{b} F_{1,14}=68.14, p<0.001\right)$. Ammonium oxidation rates in association with mussels or in seawater alone did not differ between day and night $\left(F_{1,11}=0.58, p=0.461\right)$, while nitrate reduction in seawater was greater during the day $\left(F_{1,14}=5.83\right.$, $p=0.030$ ). Boxplots as in Fig. 1. Changes to the isotopes of inorganic nitrogen are shown in Fig. A1.

the rate with bioballs and the red alga Prionitis, as well as an order of magnitude more than that for seawater alone (Fig. 1f).

Our estimates of mussel or algal mass within each chamber resulted in per-gram estimates of the effect of these macrobiota on nitrogen transformation rates. For every gram of mussel dry mass, $3.21 \mathrm{nmol}(\mathrm{se}=0.64)$ of ammonium was oxidized per liter per hour, while $1.60 \mathrm{nmol}$ of nitrate was reduced (se $=0.41$ ) (Table 1). A comparable contribution is made per gram of Prionitis wet mass with $1.50 \mathrm{nmol}$ ammonium oxidized per hour ( $\mathrm{se}=0.27$ ) and $1.56 \mathrm{nmol}$ nitrate reduced per hour $(\mathrm{se}=0.72$ ).

\subsection{Day versus night nitrogen transformations}

There was no difference between daytime and nighttime nitrification rates in association with mussels or in seawater alone (Fig. 2, $F_{1,11}=0.583, p=0.461$ ), recalling that mussel-associated ammonium oxidation rates were 2 or- ders of magnitude higher than for seawater only. Seawater nitrate reduction rates during the day $\left(1.15 \mathrm{nmol} \mathrm{L}^{-1} \mathrm{~h}^{-1}\right)$ were 4 times greater than those at night $\left(0.26 \mathrm{nmol} \mathrm{L}^{-1} \mathrm{~h}^{-1}\right.$, Fig. $2 \mathrm{~b}$; day $>$ night, $F_{1,14}=5.83, p=0.030$ ), also keeping in mind that overall rates were 10 times higher when mussels were present as compared to only seawater (mussels $>$ seawater, $\left.F_{1,14}=68.1, p<0.001\right)$.

DIN uptake in chambers could be due to both microbial transformations or seaweed uptake. Comparing tracer-based rate estimates with changes in concentration, we find that nitrate reduction accounted for as little as $4.2 \%$ of the decrease in nitrate concentration during the day, but as much as $87.2 \%$ at night. Estimates of ammonium oxidation revealed that ammonium oxidation made up $5.2 \%-7.4 \%$ of total ammonium uptake during the day. 

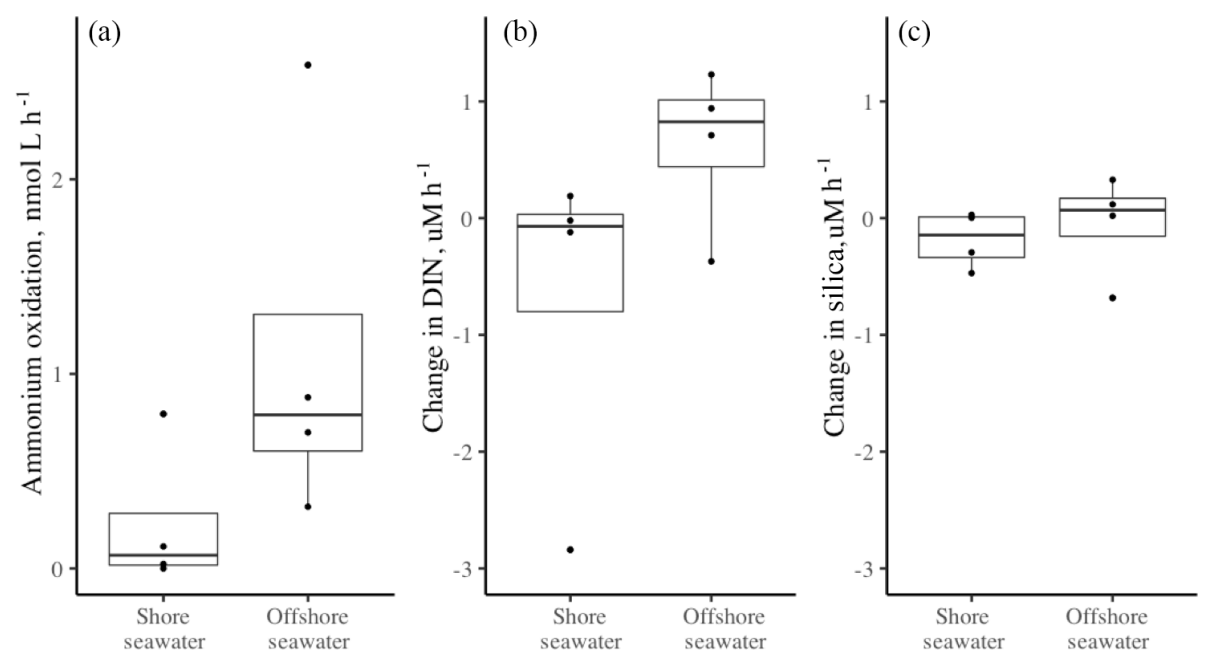

Figure 3. (a) The ammonium oxidation rate $\left(\mathrm{nmol} \mathrm{L}^{-1} \mathrm{~h}^{-1}\right)$ in surface seawater collected at the shore versus $2-5 \mathrm{~km}$ offshore, based on four trials in each locale in June and July of 2012. The rates did not differ $\left(t=t_{3.8}=1.65, p=0.177\right)$. The change in (b) DIN and (c) silica $\left(\mathrm{nmol} \mathrm{h}^{-1}\right)$ also did not differ whether seawater was from the shore or offshore (b DIN $t_{3.8}=1.31, p=.260 ; \mathbf{c}$ silica $\left.t_{3.8}=0.68, p=0.525\right)$. Boxplots as in Fig. 1.

\subsection{Onshore versus offshore microbial nitrogen transformations}

The seawater-only chambers showed no difference in ammonium oxidation (nitrification) rates whether collected at the shore $\left(\right.$ mean $\left.=0.23 \mathrm{nmol} \mathrm{L}^{-1} \mathrm{~h}^{-1}\right)$ or offshore $($ mean $=1.12$, Fig. $\left.3 \mathrm{a}, t_{3.8}=1.65, p=0.177\right)$, although the sample size was low $(n=4)$. Overall, there was little change in nutrient concentration when seawater from either offshore or nearshore was isolated; the overall mean change in DIN was less than $1 \mu \mathrm{M}$ for both nearshore $(-0.70)$ and offshore (0.63), with no significant difference between them $(t=$ $1.31, p=0.260$ ). There was also no difference in silicate uptake between the two regions $(t=-0.679, p=0.525)$, indicating that diatom activity did not differ in the two regions.

\subsection{Nitrogen transformation rates with added DOC}

On average, the coastal seawater that was used in the chambers had a DOC concentration of $145 \mu \mathrm{M}$; replicates with the addition of glucose increased DOC approximately 6 times that amount to $1000 \mu \mathrm{M}$. In the presence of Prionitis, DOC also increased with a mean of $9.31 \mathrm{mmol} \mathrm{L}^{-1} \mathrm{~h}^{-1}$ over the course of the experiment $(n=4)$. Nitrification rates did not change significantly when glucose was added (Fig. 4a), although we acknowledge that our sample size was small and nitrification was not detected in some instances across both treatments, perhaps impeding a strong test of glucose effects as nitrification was not detected in some instances across both treatments. However, DOC addition did change nutrient uptake rates. The addition of DOC to experimental chambers with Prionitis, bioballs, or in seawater alone generally resulted in greater uptake of nitrite and nitrate with Prioni- tis, bioballs, or in seawater alone while ammonium showed a trend toward greater uptake only with Prionitis; otherwise there was little overall change in ammonium concentration (Fig. 4b, c, d). DOC addition was also associated with an increased uptake of DIN and phosphorus, regardless of the composition of the chamber (Fig. 4e, f). Silica was unchanged with bioballs or seawater alone, while there was greater uptake of silicate with Prionitis, suggesting Prionitis hosts diatoms (Fig. 4g).

The greater uptake of DIN in chambers with supplemental DOC could be due to increased microbial assimilation and respiration or both with DOC. The effect of glucose on the uptake of DIN or phosphorus did not differ based on whether seawater, bioballs, or Prionitis were in the chamber $\left(F_{2.31}=0.645, p=0.531 ;\right.$ and $F_{2.31}=0.264, p=0.770$, respectively), suggesting that the background metabolism of heterotrophic bacteria was the same regardless of the macrobiota or substrate available. If microbial respiration increased with added DOC, we were unable to detect it by measuring oxygen concentrations. Whether we pooled treatments for seawater, bioballs, and Prionitis or examined them separately, dissolved oxygen measurements did not differ $(t=1.125, p=0.277, \mathrm{~d} f=16)$.

\section{Discussion}

\subsection{Seascape scale importance of macrobiota for microbial $\mathbf{N}$ metabolism}

The per-mass estimates of microbial nitrogen transformations that we measured reveal significant macrobiotaassociated microbial processing rates along coastal shore- 

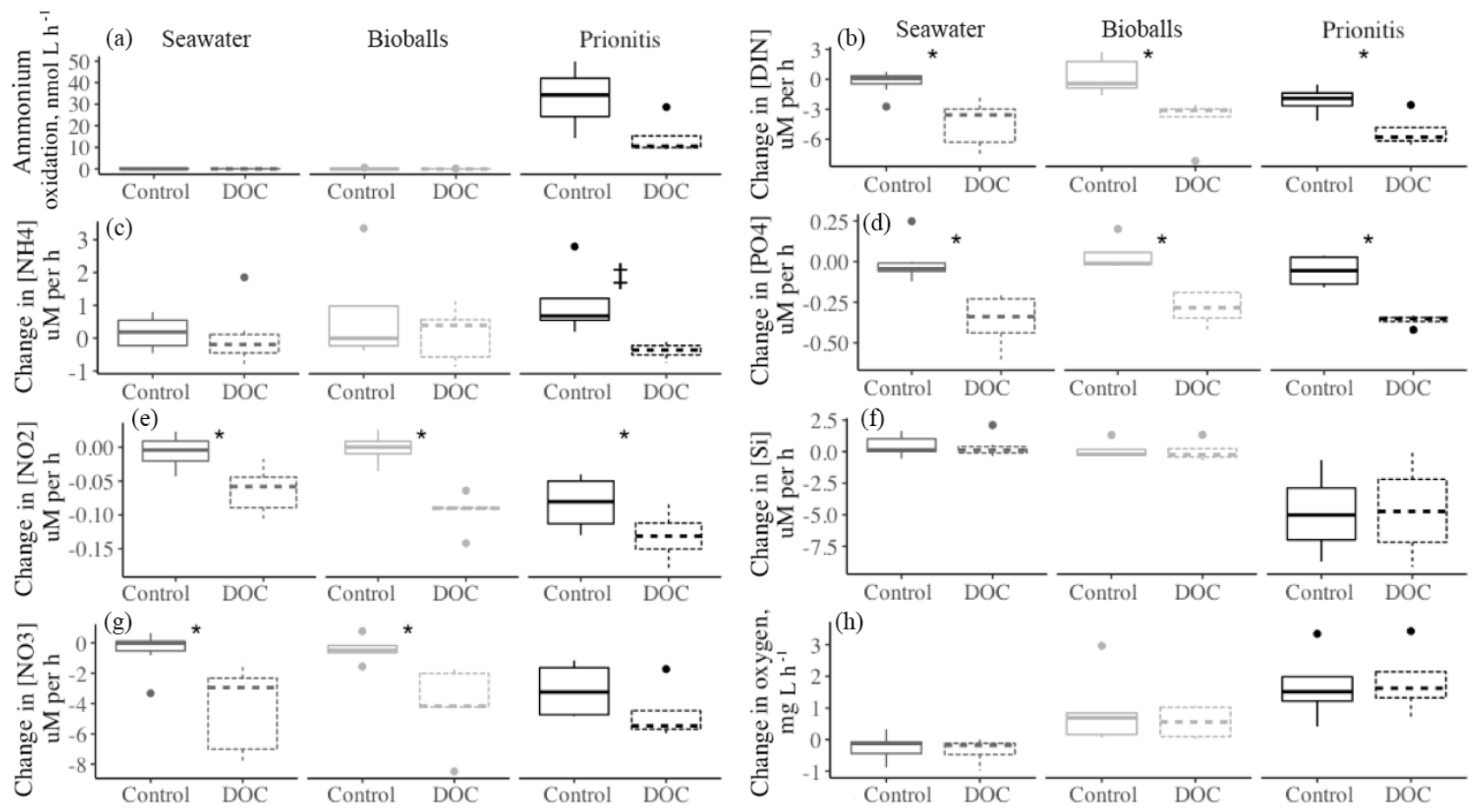

Figure 4. The effect of supplemental DOC on (a) the rate of ammonium oxidation (in $\mathrm{nmol} \mathrm{L}^{-1} \mathrm{~h}^{-1}$ ), (b-g) the change in nutrient concentrations $\left(\mu \mathrm{Mh}^{-1}\right)$, and $(\mathbf{h})$ the oxygen concentration (in $\mathrm{mg} \mathrm{L}^{-1} \mathrm{~h}^{-1}$ ). An $*$ indicates a significant difference $(p<0.05)$ between the control and the DOC addition for seawater alone, seawater with bioballs, or the red alga Prionitis. Double dagger indicates $0.10>p<0.05$. Boxplots as in Fig. 1.

lines. Studies from Wootton (2004) estimate that a square meter of mussel bed can contain $32425 \mathrm{~g}$ dry mass of mussel. Extrapolating from our measurements for both day and night, microbial nitrification in a square meter of mussel bed would amount to $2.5 \mathrm{mmol} \mathrm{day}^{-1}(+0.5 \mathrm{SE})$, with an additional $1.2 \mathrm{mmol}$ of nitrate reduction (+0.3SE) (Table 1). As a comparison, at this site it would take a volume of seawater of 1 million $\mathrm{L}$ to host the same microbial nitrogen metabolism, the equivalent of a $10 \mathrm{~m}$ by $10 \mathrm{~m}$ area of the ocean to $10 \mathrm{~m}$ depth $\left(1000 \mathrm{~m}^{3}\right)$.

A similar calculation can be done for macroalgae using Paine's (2002) estimates of macroalgal mass in control plots in the intertidal at Tatoosh Island $\left(8.6 \mathrm{~kg} \mathrm{~m}^{-2}\right)$. If Prionitis has any functional similarity to other seaweeds sampled by Paine (2002), then ammonium oxidation could reach $0.13 \mathrm{mmol} \mathrm{day}^{-1}(+0.08 \mathrm{SE})$ for a square meter of seaweed with a mass of $8.6 \mathrm{~kg}$, while nitrate reduction would occur at approximately the same rate (Table 1 ). While these rates are an order of magnitude lower than mussels, the macroalga contribution is still substantial and comparable to water column nitrification or nitrate reduction only when we consider a volume greater than $129000 \mathrm{~L}$ or a sea surface area in excess of a meter on a side and $10 \mathrm{~m}$ depth. Even if Prionitis is exceptional with respect to microbial function when compared with other seaweeds, the potential contribution of macroalgae to microbial function could be substantial. Thus, independent of macroalgal effects on DIN uptake (Fig. 1a, b, c) or ammonium remineralization by mussels (Fig. 1f), the microbiome of each of these species makes distinct contributions to nitrogen cycling. Our measurements emphasize the quantitative importance of common nearshore species to the nitrogen cycle and highlight how nearshore areas may differ from those offshore.

We demonstrated that seawater isolated from the immediate vicinity of benthic substrates had similar rates of nitrogen metabolism to offshore water (Fig. 3). As this measurement indicates no difference in the activity of suspended microbes, we conclude that microbial metabolism was elevated due to microbes directly associated with the mussel and the red alga. Previous analyses of 16s rRNA sequencing of mussel tissue, mussel shell, Prionitis, seawater, and inert surfaces show that microbial communities can be distinct on these substrates (Pfister et al., 2014b). Further, metagenomic analysis of mussel shell microbes indicates DNA sequences associated with a diversity of nitrogen metabolisms (Pfister et al., 2010). The similarity of nearshore to offshore microbial function would appear at odds with our previous work showing that natural isotopes of ammonium and nitrate $\left(\delta^{15} \mathrm{~N}_{\mathrm{NH}_{4}}\right.$ and $\left.\delta^{15} \mathrm{~N}_{\mathrm{NO}_{3}}\right)$ are enriched near the shore, indicating increased microbial processing. However, the nearshore results likely reflect benthic-associated activity influencing adjacent seawater. 
The rates of ammonium oxidation reported here in association with mussels and red algae greatly exceeded not only our estimates for seawater alone, but also those reported previously for water column rates. Our macrobiota-associated rates of ammonium oxidation (Fig. 1) were at least 2 orders of magnitude greater than a compilation of open-ocean areas (Beman et al., 2011). Similarly, other seawater assays in coastal areas of the eastern Pacific Ocean showed nitrification rates on the order of $1-10 \mathrm{nmol} \mathrm{L}^{-1} \mathrm{day}^{-1}$ (Santoro et al., 2010; Fernandez and Farías, 2012), comparable to the seawater rates we report in the absence of benthic species. When mussels were present in our chambers, the estimated rates of ammonium oxidation were $3.21 \mathrm{nmol} \mathrm{g}^{-1}$, a value comparable to those reported by Heisterkamp et al. (2013) for snails and mussels and by Welsh and Castadelli (2004) for bivalves. Thus, through genetic and biogeochemical analyses, there is increasing evidence for diverse and quantitatively significant nitrogen metabolisms in association with macrofauna.

\subsection{Microbial metabolism and dissolved organic carbon}

When considering the effect of DOC in microbial assemblages, there are three groups of microbes that might be affected. There are nitrifiers that are either heterotrophic or chemolithotrophic (Ward, 2008), as well as heterotrophic bacteria that might consume DOC and assimilate ammonium, but not nitrify (e.g., Kirchman, 1994). Thus, added DOC might be expected to increase heterotrophic nitrification if DOC was limiting nitrifier growth. Alternatively, added DOC could decrease nitrification if generalist heterotrophic bacteria assimilating ammonium were stimulated and were to then outcompete chemolithotrophs oxidizing ammonium (Butturini and Sabater, 2000), although we do not know if ammonium was ever limiting. A third possibility is that heterotrophic nitrifiers are such a small percentage of nitrification activity that there is no detectable effect of elevated DOC. We found mixed evidence for the effects of DOC on nitrification. Ammonium oxidation was never stimulated by DOC (Fig. 4); if anything, there was a nonsignificant trend of decreased ammonium oxidation with glucose, suggesting that general heterotrophic bacteria were consuming the elevated DOC. Our DOC additions were accompanied by decreased dissolved inorganic nitrogen and phosphorus in the surrounding seawater, suggesting that heterotrophic microbial metabolism increased, a result consistent with other glucose-addition studies with microbes (Zhang et al., 2013). Bacterial production in seawater has been shown to increase with glucose addition (Caron et al., 2000; Jacquet et al., 2002), with heterotrophic bacteria released from carbon limitation when DOC is added (Jacquet et al., 2002; Joint et al., 2002). In streams, glucose additions have resulted in decreased nitrification (Strauss and Lamberti, 2000), a result attributed to heterotrophic bacteria in di- rect competition with nitrifiers. While Strauss and Lamberti (2000) documented decreased oxygen concentration and increased respiration with added DOC, we detected no effect of DOC on the change in oxygen within chambers (Fig. 4h). The unknown contribution of photosynthesis to oxygen concentrations, as well as the relatively high oxygen content of the seawater in these locales, could have masked oxygen differences. Nonetheless, DOC stimulated nutrient uptake, presumably by heterotrophic microbes, and the effect of DOC was the same whether seawater, bioballs, or Prionitis were in the chamber (Fig. 4b-i). Thus, the background metabolism of heterotrophic bacteria was unchanged even when Prionitis was present and reduced chamber DIN concentrations $6.5 \mu \mathrm{M}$ over the course of the experimental runs.

A final explanation for increased DIN uptake with added DOC is that bacteria are able to compete with any phototrophs for nitrate when an organic carbon source is increased (e.g., Diner et al., 2016). Nitrate reduction rates are high with Prionitis and this alga also provisions DOC, perhaps promoting the coupling of heterotrophy and nitrate reduction. Whether any of the decreased nitrate concentration associated with Prionitis in chambers could be attributed to heterotrophic nitrate reduction is unknown at this time, because our experiments with added DOC did not assay nitrate reduction, only ammonium oxidation.

In sum, while DOC concentrations can be elevated in nearshore areas compared with offshore, there was little evidence that enhanced DOC changed nitrification rates, even in the chambers with Prionitis, where DIN levels were lower due to seaweed uptake. Whether heterotrophic nitrifiers are present remains unknown, though previous analysis of microbes at these sites suggests the presence of taxa associated with heterotrophic nitrification, e.g., Arthrobacter (Hynes and Knowles, 1982), Crenarchaeota (Offre et al., 2013), and Alcaligenes faecalis (Joo et al., 2005), though they were detected in only a small fraction of samples (Pfister et al., 2014b). Analyses of 16s rRNA of seawater, mussels, and Prionitis do show sharp distinctions in $\beta$-diversity, with some taxa unique to each (Pfister et al., 2014b).

Taken together our data suggest that chemolithotrophic nitrifiers are dominating nitrification in this area. Other heterotrophic bacteria can noticeably depress DIN and phosphate concentrations when DOC is supplemented, suggesting there may be some carbon limitation for heterotrophic microbial metabolisms. If, as suggested by Strauss and Lamberti (2000), the $\mathrm{C}: \mathrm{N}$ ratio available to microbes, either in the water column or in the substrate they are using, determines the relative fitness of heterotrophic bacteria versus chemolithotrophic nitrifiers, then the many regions where DIN concentrations in seawater are lower than they are at our Washington coastal sites may show a different result.

Of note is that many seaweeds produce detectable amounts of DOC in coastal areas (Wada and Hama, 2013), with as much as $14 \%$ of net primary production being released as DOC in a kelp species (Reed et al., 2015). Among other sea- 
weeds, $20 \%$ to $30 \%$ of released DOC can be taken up within $2 \mathrm{~h}$ (Brylinsky, 1977), suggesting an active heterotrophic assemblage in proximity. Seaweeds also have a diverse assemblage of microbial associates (Lemay et al., 2018; Marzinelli et al., 2018; Michelou et al., 2013; Pfister et al., 2014b). Which of these associated microbes benefit from this DOC and whether others are inhibited is unknown. While we tested the effect of elevated glucose on nitrification with ${ }^{15} \mathrm{~N}$ enriched ammonium, a next step is to test if those microbes involved in the nitrate reduction pathways are affected by glucose addition.

Macrobiota that serve as hosts for microbes provide a predictable substrate for attachment in a fluid environment and provide dissolved organic matter in many forms (Carlson and Hansell, 2015). The mussels studied here also excrete ammonium and likely DON (Bayne and Scullard, 1977; Pather et al., 2014). Their filter-feeding activities release DOC in many forms and continually process organic matter that can be utilized by microbes (Jacobs et al., 2015). Through filter feeding and mucus production, there is increasing evidence that marine invertebrates and microbes are connected through their production and use of dissolved organic matter (Rädecker et al., 2015; Rix et al., 2016).

\subsection{The multiple factors influencing nitrogen availability}

Our experiments provide insight into the fate of nitrogen in coastal systems. While ammonium oxidation and nitrate reduction rates were 2 orders of magnitude higher than any water column estimates, we have no evidence that nitrate reduction continued through to denitrification and the release of $\mathrm{N}_{2}$ gas as we never detected enriched ${ }^{15} \mathrm{~N}$ in $\mathrm{N}_{2}$ gas (e.g., Jensen et al., 2011), despite our ability to detect a $1.0 \%$ onrichment in $\mathrm{N}_{2}$ gas. Thus, nitrogen was being retained in our experimental system. If ammonium oxidation and nitrate reduction are occurring relatively constantly, as suggested by our experiments, then a diversity of microbially mediated DIN dynamics may take place across microenvironments that differ in oxygen levels. The net result could be continued microbial use of ammonium and nitrate and the ability for the microenvironment surrounding the animal or seaweed to sustain a range of microbial metabolisms, a result obtained for other marine invertebrates (de Goeij et al., 2013; Heisterkamp et al., 2013). Research in tide pools containing these same species has also shown both nitrogen oxidation and reduction processes (Pfister et al., 2016). In all instances to date, the metabolism of the host macrobiota results in a daily range of oxygen levels, thus providing a diversity of environmental niches that favor different microbial transformations through time.

\section{Conclusions}

The marine mussel and alga species studied here were loci for microbial nitrogen metabolism, with a square meter of mussel bed contributing $2.5 \mathrm{mmol}$ of microbial ammonium use via ammonium oxidation and $1.2 \mathrm{mmol}$ of nitrate reduction per day, as well as with rates 2 orders of magnitude over that of seawater alone. Seaweed nitrification and nitrate reduction was also elevated above seawater at $0.13 \mathrm{mmol} \mathrm{m}^{-2} \mathrm{day}^{-1}$. For mussels, microbial nitrogen processing did not differ between daylight and nighttime hours. While the addition of DOC did not increase ammonium oxidation, it resulted in greater uptake of DIN, suggesting that DOC stimulated heterotrophic microbial activity. In addition to providing a template for a diverse set of ecological interactions, the marine macrobiota studied here hosted a diverse set of microbial metabolisms and enhanced rates of carbon and nitrogen cycling in coastal ecosystems.

Code and data availability. The data used in this study are available from the authors upon request. 


\section{Appendix A}
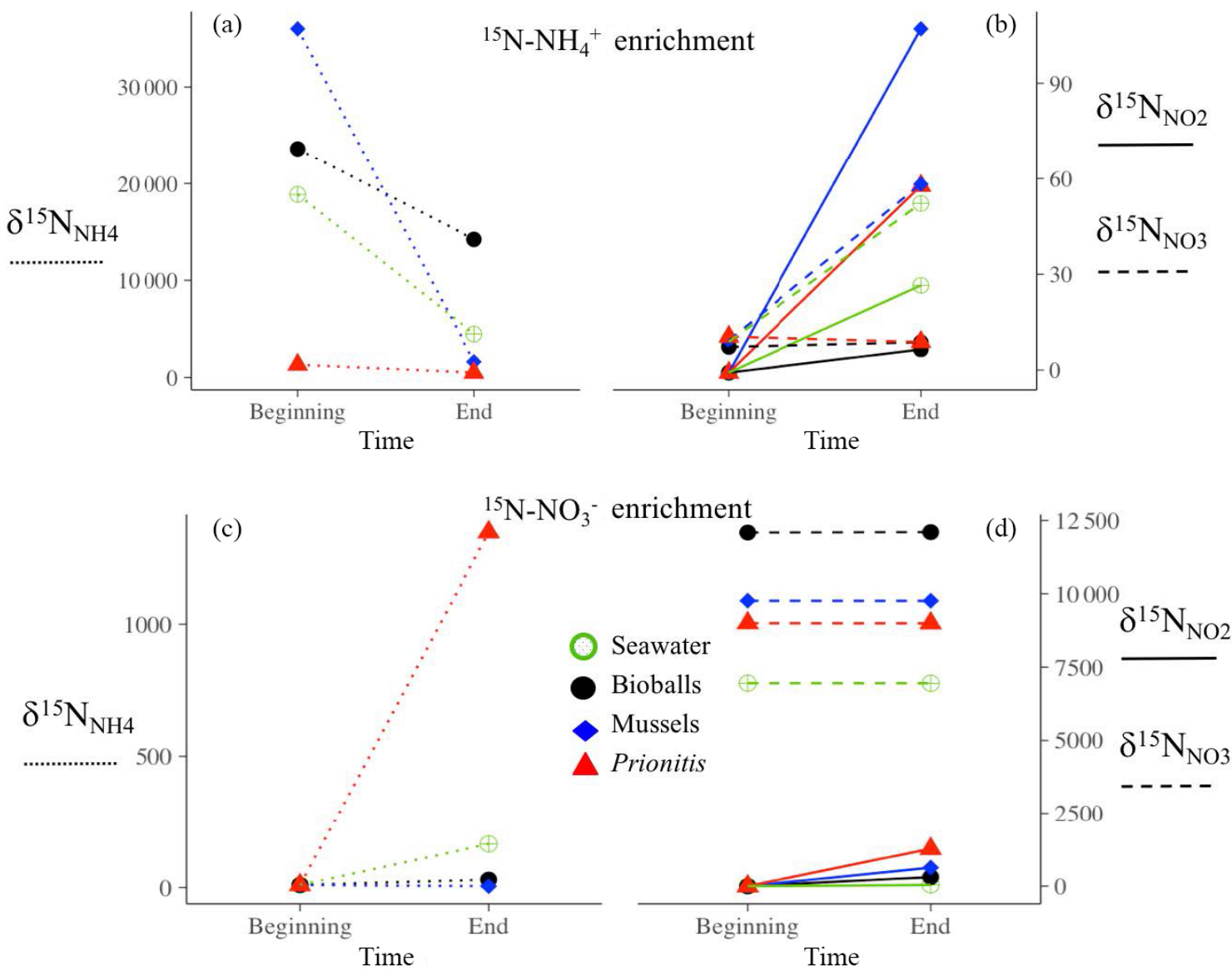

Figure A1. An example of each substrate type in an enrichment with ${ }^{15} \mathrm{~N}-\mathrm{NH}_{4}^{+}$(a, b) and ${ }^{15} \mathrm{~N}-\mathrm{NO}_{3}^{-}$(c, d). When ${ }^{15} \mathrm{~N}-\mathrm{NH} H_{4}^{+}$was added, enrichment in $\delta^{15} \mathrm{~N}_{\mathrm{NO}_{2}}$ (solid line) and $\delta^{15} \mathrm{~N}_{\mathrm{NO}_{3}}$ (dashed line) was measured (b), while enrichment in $\delta^{15} \mathrm{~N}_{\mathrm{NH}_{4}}\left(\right.$ dotted line, c) and $\delta^{15} \mathrm{~N}_{\mathrm{NO}_{2}}$ (d) followed the addition of ${ }^{15} \mathrm{~N}-\mathrm{NO}_{3}^{-}$. Ammonium regeneration in the chambers, particularly mussels, diluted the $\delta^{15} \mathrm{~N}_{\mathrm{NH}}$ signal (a and Fig. 1f). Deviations in our target of initial enrichment (10000\%o and 2000\%o) occurred due to natural variation in nutrient concentrations at the time of tracer addition. 
Supplement. The supplement related to this article is available online at: https://doi.org/10.5194/bg-16-193-2019-supplement.

Author contributions. Both authors designed the study. CAP conducted the experiment. MAA analyzed isotopic data. Both authors prepared the manuscript.

Competing interests. The authors declare that they have no conflict of interest.

Acknowledgements. We are grateful to the Makah Tribal Council for access to Tatoosh Island and Second Beach. We thank Sam Betcher, Lyda Harris, Gregor Siegmund, Kellen Thomas, Anna, Ben and Tim Wootton for help in the field; Jen Larkum for analyzing seawater isotopes; and Santhiska Pather for foundational work. Brooke Weigel provided helpful feedback and discussion. Three anonymous reviewers improved a previous version of the manuscript. The University of Chicago physics shop ably helped with the design and construction of the chambers. Funding was provided by NSF-OCE 09-28232 (CAP) and NSF-OCE 09-28152 (MAA). Captain Ray McQuin and the crew of the R/V Clifford A. Barnes, especially Jim Postels, facilitated the offshore sampling.

Edited by: Clare Woulds

Reviewed by: three anonymous referees

\section{References}

Allgeier, J. E., Layman, C. A., Mumby, P. J., and Rosemond, A. D.: Consistent nutrient storage and supply mediated by diverse fish communities in coral reef ecosystems, Glob. Change Biol., 20, 2459-2472, https://doi.org/10.1111/gcb.12566, 2014.

Azam, F.: Microbial Control of Oceanic Carbon Flux: The Plot Thickens, Science, 280, 694-696, https://doi.org/10.1126/science.280.5364.694, 1998.

Bayne, B. L. and Scullard, C.: Rates of nitrogen excretion by species of Mytilus (Bivalvia: Mollusca), J. Mar. Biol. Assoc. U. K., 57, 355-369, https://doi.org/10.1017/S0025315400021809, 1977.

Beman, J. M., Chow, C.-E., King, A., Feng, Y., Fuhrman, J. A., Andersson, A., and Bates, N. R.: Global declines in ocean nitrification rates as a consequence of ocean acidification, P. Natl. Acad. Sci., 108, 208-213, 2011.

Brylinsky, M.: Release of dissolved organic matter by some marine macrophytes, Mar. Biol., 39, 213-220, https://doi.org/10.1007/BF00390995, 1977.

Butturini, A. and Sabater, F.: Seasonal variability of dissolved organic carbon in a Mediterranean stream, Biogeochemistry, 51, 303-321, https://doi.org/10.1023/A:1006420229411, 2000.

Capone, D. G., Bronk, D. A., Mulholland, M. R., and Carpenter, E. J.: Nitrogen in the Marine Environment, Academic Press, 2008.

Carlson, C. A. and Hansell, D. A.: DOM Sources, Sinks, Reactivity, and Budgets, in Biogeochemistry of Marine Dissolved Organic Matter, pp. 65-126, Elsevier., 2015.
Caron, D., Lim, E., Sanders, R., Dennett, M., and Berninger, U.: Responses of bacterioplankton and phytoplankton to organic carbon and inorganic nutrient additions in contrasting oceanic ecosystems, Aquat. Microb. Ecol., 22, 175-184, https://doi.org/10.3354/ame022175, 2000.

Charoenpong, C. N., Bristow, L. A., and Altabet, M. A.: A continuous flow isotope ratio mass spectrometry method for high precision determination of dissolved gas ratios and isotopic composition, Limnol. Oceanogr. Methods, 12, 323-337, https://doi.org/10.4319/lom.2014.12.323, 2014.

Clasen, J. L. and Shurin, J. B.: Kelp forest size alters microbial community structure and function on Vancouver Island, Canada, Ecology, 96, 862-872, https://doi.org/10.1890/13-2147.1, 2015.

Croll, D. A.: Introduced predators transform Subarctic islands from grassland to tundra, Science, 307, 1959-1961, https://doi.org/10.1126/science.1108485, 2005.

de Goeij, J. M., van Oevelen, D., Vermeij, M. J. A., Osinga, R., Middelburg, J. J., de Goeij, A. F. P. M., and Admiraal, W.: Surviving in a marine desert: The sponge loop retains resources within coral reefs, Science, 342, 108-110, https://doi.org/10.1126/science.1241981, 2013.

Diner, R. E., Schwenck, S. M., McCrow, J. P., Zheng, H., and Allen, A. E.: Genetic manipulation of competition for nitrate between heterotrophic bacteria and diatoms, Front. Microbiol., 7, 880, https://doi.org/10.3389/fmicb.2016.00880, 2016.

Eyre, B. D., Ferguson, A. J. P., Webb, A., Maher, D., and Oakes, J. M.: Denitrification, N-fixation and nitrogen and phosphorus fluxes in different benthic habitats and their contribution to the nitrogen and phosphorus budgets of a shallow oligotrophic sub-tropical coastal system (southern Moreton Bay, Australia), Biogeochemistry, 102, 111-133, https://doi.org/10.1007/s10533010-9425-6, 2011.

Fernandez, C. and Farías, L.: Assimilation and regeneration of inorganic nitrogen in a coastal upwelling system: ammonium and nitrate utilization, Mar. Ecol. Prog. Ser., 451, 1-14, https://doi.org/10.3354/meps09683, 2012.

Flombaum, P., Gallegos, J. L., Gordillo, R. A., Rincon, J., Zabala, L. L., Jiao, N., Karl, D. M., Li, W. K. W., Lomas, M. W., Veneziano, D., Vera, C. S., Vrugt, J. A., and Martiny, A. C.: Present and future global distributions of the marine Cyanobacteria Prochlorococcus and Synechococcus, P. Natl. Acad. Sci., 110, 9824-9829, https://doi.org/10.1073/pnas.1307701110, 2013.

Fowler, D., Coyle, M., Skiba, U., Sutton, M. A., Cape, J. N., Reis, S., Sheppard, L. J., Jenkins, A., Grizzetti, B., Galloway, J. N., Vitousek, P., Leach, A., Bouwman, A. F., ButterbachBahl, K., Dentener, F., Stevenson, D., Amann, M., and Voss, M.: The global nitrogen cycle in the twenty-first century, Philos. T. Roy. Soc. Lond. B Biol. Sci., 368, 20130164, https://doi.org/10.1098/rstb.2013.0164, 2013.

Francis, C. A., Beman, J. M., and Kuypers, M. M. M.: New processes and players in the nitrogen cycle: the microbial ecology of anaerobic and archaeal ammonia oxidation, ISME J., 1, 1927, https://doi.org/10.1038/ismej.2007.8, 2007.

Galloway, J. N., Townsend, A. R., Erisman, J. W., Bekunda, M., Cai, Z., Freney, J. R., Martinelli, L. A., Seitzinger, S. P., and Sutton, M. A.: Transformation of the nitrogen cycle: recent trends, questions, and potential solutions, Science, 320, 889-892, https://doi.org/10.1126/science.1136674, 2008. 
Glibert, Pamela M., Lipschultz, F., McCarthy, James J., and Altabet, M. A.: Isotope dilution models of uptake and remineralization of ammonium by marine plankton, Limnol. Oceanogr., 27, 639650,1982

Grossmann, S. and Reichardt, W.: Impact of Arenicola marina on bacteria in intertidal sediments, Mar. Ecol. Prog. Ser., 77, 85-93, 1991.

Hansell, D. A. and Carlson, C. A. (Eds.): Biogeochemistry of marine dissolved organic matter, Second edition, Academic Press, Amsterdam, Boston, 2015.

Heisterkamp, I., Schramm, A., de Beer, D., and Stief, P.: Nitrous oxide production associated with coastal marine invertebrates, Mar. Ecol. Prog. Ser., 415, 1-9, https://doi.org/10.3354/meps08727, 2010.

Heisterkamp, I. M., Schramm, A., Larsen, L. H., Svenningsen, N. B., Lavik, G., de Beer, D., and Stief, P.: Shell biofilmassociated nitrous oxide production in marine molluscs: processes, precursors and relative importance: Nitrous oxide production in shell biofilms, Environ. Microbiol., 15, 1943-1955, https://doi.org/10.1111/j.1462-2920.2012.02823.x, 2013

Hynes, R. K. and Knowles, R.: Effect of acetylene on autotrophic and heterotrophic nitrification, Can. J. Microbiol., 28, 334-340, https://doi.org/10.1139/m82-049, 1982.

Jacobs, P., Riegman, R., and van der Meer, J.: Impact of the blue mussel Mytilus edulis on the microbial food web in the western Wadden Sea, The Netherlands, Mar. Ecol. Prog. Ser., 527, 119131, https://doi.org/10.3354/meps11227, 2015.

Jacquet, S., Havskum, H., Thingstad, T., and Vaulot, D.: Effects of inorganic and organic nutrient addition on a coastal microbial community (Isefjord, Denmark), Mar. Ecol. Prog. Ser., 228, 314, https://doi.org/10.3354/meps228003, 2002.

Jensen, M. M., Lam, P., Revsbech, N. P., Nagel, B., Gaye, B., Jetten, M. S., and Kuypers, M. M.: Intensive nitrogen loss over the Omani Shelf due to anammox coupled with dissimilatory nitrite reduction to ammonium, ISME J., 5, 1660-1670, https://doi.org/10.1038/ismej.2011.44, 2011.

Joint, I., Henriksen, P., Fonnes, G., Bourne, D., Thingstad, T., and Riemann, B.: Competition for inorganic nutrients between phytoplankton and bacterioplankton in nutrient manipulated mesocosms, Aquat. Microb. Ecol., 29, 145-159, https://doi.org/10.3354/ame029145, 2002.

Joo, H.-S., Hirai, M., and Shoda, M.: Characteristics of ammonium removal by heterotrophic nitrification-aerobic denitrification by Alcaligenes faecalis, J. Biosci. Bioeng., 100, 184-191, https://doi.org/10.1263/jbb.100.184, 2005.

Kirchman, D. L.: The uptake of inorganic nutrients by heterotrophic bacteria, Microb. Ecol., 28, 255-271, https://doi.org/10.1007/BF00166816, 1994.

Layman, C. A., Allgeier, J. E., Rosemond, A. D., Dahlgren, C. P., and Yeager, L. A.: Marine fisheries declines viewed upside down: human impacts on consumer-driven nutrient recycling, Ecol. Appl., 21, 343-349, https://doi.org/10.1890/10-1339.1, 2011.

Lemay, M. A., Martone, P. T., Keeling, P. J., Burt, J. M., Krumhansl, K. A., Sanders, R. D., and Wegener Parfrey, L.: Sympatric kelp species share a large portion of their surface bacterial communities: Kelp-associated bacterial diversity, Environ. Microbiol., 20, 658-670, https://doi.org/10.1111/1462-2920.13993, 2018.

Lipschultz, F.: Isotope tracer methods for studies of the marine nitrogen cycle, in: Nitrogen in the Marine Environment (2nd
Edition), edited by: Capone, D. G., Bronk, D. A., Mulholland, M. R., and Carpenter, E. J., 1345-1384, Academic Press, San Diego, available at: http://www.sciencedirect.com/science/ article/pii/B9780123725226000311 (last access: January 2019), 2008.

Maranger, R., Caraco, N., Duhamel, J., and Amyot, M.: Nitrogen transfer from sea to land via commercial fisheries, Nat. Geosci, 1, 111-112, https://doi.org/10.1038/ngeo108, 2008.

Marzinelli, E. M., Qiu, Z., Dafforn, K. A., Johnston, E. L., Steinberg, P. D., and Mayer-Pinto, M.: Coastal urbanisation affects microbial communities on a dominant marine holobiont, Npj Biofilms Microbiomes, 4, 1, https://doi.org/10.1038/s41522017-0044-z, 2018.

McIlvin, M. R. and Altabet, M. A.: Chemical Conversion of Nitrate and Nitrite to Nitrous Oxide for Nitrogen and Oxygen Isotopic Analysis in Freshwater and Seawater, Anal. Chem., 77, 55895595, https://doi.org/10.1021/ac050528s, 2005.

Michelou, V. K., Caporaso, J. G., Knight, R., and Palumbi, S. R.: The ecology of microbial communities associated with Macrocystis pyrifera, PLoS ONE, 8, e67480, https://doi.org/10.1371/journal.pone.0067480, 2013.

Moulton, O. M., Altabet, M. A., Beman, J. M., Deegan, L. A., Lloret, J., Lyons, M. K., Nelson, J. A., and Pfister, C. A.: Microbial associations with macrobiota in coastal ecosystems: patterns and implications for nitrogen cycling, Front. Ecol. Environ., 14, 200-208, https://doi.org/10.1002/fee.1262, 2016.

Murray, R. H., Erler, D. V., and Eyre, B. D.: Nitrous oxide fluxes in estuarine environments: response to global change, Glob. Change Biol., 21, 3219-3245, https://doi.org/10.1111/gcb.12923, 2015.

Offre, P., Spang, A., and Schleper, C.: Archaea in Biogeochemical Cycles, Annu. Rev. Microbiol., 67, 437-457, https://doi.org/10.1146/annurev-micro-092412-155614, 2013.

Paine, R. T.: Trophic control of production in a rocky intertidal community, Science, 296, 736-739, https://doi.org/10.1126/science.1069811, 2002.

Pather, S., Pfister, C. A., Post, D. M., and Altabet, M. A.: Ammonium cycling in the rocky intertidal: Remineralization, removal, and retention, Limnol. Oceanogr., 59, 361-372, https://doi.org/10.4319/lo.2014.59.2.0361, 2014.

Pfister, C. A.: Intertidal invertebrates locally enhance primary production, Ecology, 88, 1647-1653, https://doi.org/10.1890/061913.1, 2007.

Pfister, C. A., Meyer, F., and Antonopoulos, D. A.: Metagenomic profiling of a microbial assemblage associated with the California mussel: A node in networks of carbon and nitrogen cycling, PLoS ONE, 5, e10518, https://doi.org/10.1371/journal.pone.0010518, 2010.

Pfister, C. A., Altabet, M. A., and Post, D.: Animal regeneration and microbial retention of nitrogen along coastal rocky shores, Ecology, 95, 2803-2814, https://doi.org/10.1890/13-1825.1, 2014a.

Pfister, C. A., Gilbert, J. A., and Gibbons, S. M.: The role of macrobiota in structuring microbial communities along rocky shores, Peer J., 2, e631, https://doi.org/10.7717/peerj.631, 2014b.

Pfister, C. A., Altabet, M. A., Pather, S., and Dwyer, G.: Tracer experiment and model evidence for macrofaunal shaping of microbial nitrogen functions along rocky shores, Biogeosciences, 13, 3519-3531, https://doi.org/10.5194/bg-13-3519-2016, 2016.

Rädecker, N., Pogoreutz, C., Voolstra, C. R., Wiedenmann, J., and Wild, C.: Nitrogen cycling in corals: the key to understand- 
ing holobiont functioning?, Trends Microbiol., 23, 490-497, https://doi.org/10.1016/j.tim.2015.03.008, 2015.

Reed, D. C., Carlson, C. A., Halewood, E. R., Nelson, J. C., Harrer, S. L., Rassweiler, A., and Miller, R. J.: Patterns and controls of reef-scale production of dissolved organic carbon by giant kelp Macrocystis pyrifera: DOC production by giant kelp, Limnol. Oceanogr., 60, 1996-2008, https://doi.org/10.1002/lno.10154, 2015.

Rix, L., de Goeij, J. M., Mueller, C. E., Struck, U., Middelburg, J. J., van Duyl, F. C., Al-Horani, F. A., Wild, C., Naumann, M. S., and van Oevelen, D.: Coral mucus fuels the sponge loop in warm- and cold-water coral reef ecosystems, Sci. Rep., 6, 18715, https://doi.org/10.1038/srep18715, 2016.

Santoro, A. E., Casciotti, K. L., and Francis, C. A.: Activity, abundance and diversity of nitrifying archaea and bacteria in the central California Current: Nitrification in the central California Current, Environ. Microbiol., 12, 1989-2006, https://doi.org/10.1111/j.1462-2920.2010.02205.x, 2010.

Schindler, D. E., Knapp, R. A., and Leavitt, P. R.: Alteration of nutrient cycles and algal production resulting from fish introductions into mountain lakes, Ecosystems, 4, 308-321, https://doi.org/10.1007/s10021-001-0013-4, 2001.

Stief, P.: Stimulation of microbial nitrogen cycling in aquatic ecosystems by benthic macrofauna: mechanisms and environmental implications, Biogeosciences, 10, 7829-7846, https://doi.org/10.5194/bg-10-7829-2013, 2013.

Strauss, E. A. and Lamberti, G. A.: Regulation of nitrification in aquatic sediments by organic carbon, Limnol. Oceanogr., 45, 1854-1859, https://doi.org/10.4319/lo.2000.45.8.1854, 2000.

Subalusky, A. L., Dutton, C. L., Rosi-Marshall, E. J., and Post, D. M.: The hippopotamus conveyor belt: vectors of carbon and nutrients from terrestrial grasslands to aquatic systems in sub-Saharan Africa, Freshw. Biol., 60, 512-525, https://doi.org/10.1111/fwb.12474, 2015.

UNESCO: Protocols for the joint global ocean flux study (JGOFS) core measurements, Vol. 29., 1994.

Vanni, M. J.: Nutrient cycling by animals in freshwater ecosystems, Annu. Rev. Ecol. Syst., 33, 341-370, https://doi.org/10.1146/annurev.ecolsys.33.010802.150519,

2002.
Wada, S. and Hama, T.: The contribution of macroalgae to the coastal dissolved organic matter pool, Estuar. Coast. Shelf Sci., 129, 77-85, https://doi.org/10.1016/j.ecss.2013.06.007, 2013.

Ward, B. B.: Nitrification, in: Nitrogen in the Marine Environment, edited by: Capone, D. G., Bronk, D. A., Mulholland, M. R., and Carpenter, E. J., 199-262, Elsevier, Amsterdam, 2008.

Ward, B. B. and Bouskill, N. J.: The utility of functional gene arrays for assessing community composition, relative abundance, and distribution of ammonia-oxidizing bacteria and archaea, Methods Enzymol., 496, 373-396, https://doi.org/10.1016/B978-012-386489-5.00015-4, 2011.

Welsh, D. T. and Castadelli, G.: Bacterial nitrification activity directly associated with isolated benthic marine animals, Mar. Biol., 144, 1029-1037, https://doi.org/10.1007/s00227003-1252-z, 2004.

Wootton, J. T.: Markov chain models predict the consequences of experimental extinctions, Ecol. Lett., 7, 653-660, https://doi.org/10.1111/j.1461-0248.2004.00621.x, 2004.

Worm, B., Barbier, E. B., Beaumont, N., Duffy, J. E., Folke, C., Halpern, B. S., Jackson, J. B. C., Lotze, H. K., Micheli, F., Palumbi, S. R., Sala, E., Selkoe, K. A., Stachowicz, J. J., and Watson, R.: Impacts of biodiversity loss on ocean ecosystem services, Science, 314, 787-790, https://doi.org/10.1126/science.1132294, 2006.

Zehr, J. P. and Ward, B. B.: Nitrogen cycling in the ocean: new perspectives on processes and paradigms, Appl. Environ. Microbiol., 68, 1015-1024, https://doi.org/10.1128/AEM.68.3.10151024.2002, 2002.

Zhang, L., Altabet, M. A., Wu, T., and Hadas, O.: Sensitive Measurement of $\mathrm{NH}_{4}^{+15} \mathrm{~N} /{ }^{14} \mathrm{~N}\left(\delta^{15} \mathrm{NH}_{4}^{+}\right)$at Natural Abundance Levels in Fresh and Saltwaters, Anal. Chem., 79, 5297-5303, https://doi.org/10.1021/ac070106d, 2007.

Zhang, R., Weinbauer, M. G., Tam, Y. K., and Qian, P.-Y.: Response of bacterioplankton to a glucose gradient in the absence of lysis and grazing, FEMS Microbiol. Ecol., 85, 443-451, https://doi.org/10.1111/1574-6941.12133, 2013. 